\title{
Cuminum cyminum Extracts as Eco-Friendly Corrosion Inhibitor for Mild Steel in Seawater
}

\author{
V. Sribharathy ${ }^{1}$ and Susai Rajendran ${ }^{2}$ \\ ${ }^{1}$ PG and Research Department, GTN Arts College, Dindigul 624005, Tamil Nadu, India \\ ${ }^{2}$ Department of Chemistry, RVS School of Engineering and Technology, Dindigul 624005, Tamil Nadu, India
}

Correspondence should be addressed to V. Sribharathy; bharathy_chem@yahoo.co.in

Received 8 October 2012; Accepted 30 October 2012

Academic Editors: C. Gervasi, I. Obot, and Q. Qu

Copyright (c) 2013 V. Sribharathy and S. Rajendran. This is an open access article distributed under the Creative Commons Attribution License, which permits unrestricted use, distribution, and reproduction in any medium, provided the original work is properly cited.

\begin{abstract}
The inhibitive effect of Jeera (Cuminum cyminum) plant extracts on the corrosion of mild steel in an aqueous solution of seawater was investigated using potentiodynamic polarization and electrochemical impedance spectroscopy (EIS) techniques. The stability of the inhibition efficiency of Jeera extracts was examined by weight-loss method. Potentiodynamic polarization curves indicated that the Jeera extract behaves as an anodic type inhibitor. EIS measurements showed that the dissolution process occurs under activation control. The corrosion rates of steel and the inhibition efficiencies of the extract obtained from impedance and polarization measurements were in good agreement. Inhibition was found to increase with an increasing concentration of the plant extract. The results obtained show that the Jeera extract could serve as an effective inhibitor for the corrosion of mild steel in seawater.
\end{abstract}

\section{Introduction}

Recently, plant extracts have again become important as an environmentally acceptable, readily available, and renewable source for a wide range of needed inhibitors. Plant extracts are viewed as an incredibly rich source of naturally synthesized chemical compounds that can be extracted by simple procedures with low cost. However, synergistic (and antagonistic) effects are often expected with these mixtures of inhibitors that may affect their inhibition efficiency. Several investigations have been reported using such economic plant extracts. El Hosary et al. [1] studied the corrosion inhibition of aluminium and zinc in $2 \mathrm{~N} \mathrm{HCl}$ using naturally occurring Hibiscus sabdariffa (Karkade) extract. The inhibition of corrosion of steel, aluminium, and copper in $\mathrm{HCl}, \mathrm{H}_{2} \mathrm{SO}_{4}$, and citric acid by molasses was also studied [2], and $83 \%$ and $13 \%$ inhibition efficiencies were obtained for $\mathrm{HCl}$ and $\mathrm{H}_{2} \mathrm{SO}_{4}$ solutions, respectively, containing $0.75 \%$ molasses. Loto reported the inhibitive action of Vernonia amygdalina (bitter leaf) on the corrosion of mild steel in $0.5 \mathrm{M} \mathrm{HCl}$ at $28^{\circ} \mathrm{C}$ [3]. Avwiri and Igho studied the inhibitive action of V. amygdalina on the corrosion of aluminium alloys in $\mathrm{HCl}$ and $\mathrm{HNO}_{3}$ at concentrations of 0.2 and $0.4 \mathrm{~g} / \mathrm{L}$ at $29^{\circ} \mathrm{C}$ [4]. They showed that the solution extract of the leaves serves as an excellent inhibitor. The inhibition effect of Zanthoxylum alatum plant extract on the corrosion of mild steel in $20 \%, 50 \%$, and $88 \%$ aqueous orthophosphoric acid has been investigated by weight loss and electrochemical impedance spectroscopy (EIS). Plant extract was found to reduce the corrosion of steel more effectively in $88 \%$ than in $20 \%$ phosphoric acid [5]. An inhibition efficiency of $75.11 \%$ was observed with the extract of the leaves of Nypa fruticans Wurmb [6] for the corrosion of mild steel in hydrochloric acid solutions. El-Etre et al. examined some naturally occurring substances as corrosion inhibitors for different metals in various environments [7-11].

The application of extracts of henna, thyme, bgugaine, and inriine was investigated for their anticorrosion activity [12-15]. The effect of addition of bgugaine on steel corrosion in $\mathrm{HCl}$ is patented [16]. Saleh and El-Hosaray studied the peel of pomegranate [17] and beetroot $[18,19]$ as corrosion inhibitor for mild steel in acid media. Sanghvi et al. have investigated the anticorrosion activity of Emblica officinalis, Terminalia chebula, Terminalia bolivia [20], Sapindus trifoliatus, and Acacia concinna [21]. Corrosion inhibition has also been studied for the extracts of Swertia angustifolia [22], Eucalyptus leaves [23], Eugenia jambolana [24], Pongamia 
TABLE 1: Water analysis.

\begin{tabular}{lc}
\hline Parameters & Result \\
\hline Total dissolved salts $(\mathrm{mg} / \mathrm{L})$ & $8000 \mathrm{ppm}$ \\
$\mathrm{pH}$ & 8.1 \\
Calcium as $\mathrm{Ca}(\mathrm{mg} / \mathrm{L})$ & $160 \mathrm{ppm}$ \\
Total hardness $(\mathrm{CaCO}$ equivalent $)$ & $100 \mathrm{ppm}$ \\
Magnesium as $\mathrm{Mg}(\mathrm{mg} / \mathrm{L})$ & $100 \mathrm{ppm}$ \\
Sodium as $\mathrm{Na}(\mathrm{mg} / \mathrm{L})$ & 0 \\
Chloride as $\mathrm{Cl}(\mathrm{mg} / \mathrm{L})$ & $17600 \mathrm{ppm}$ \\
Sulphate as $\mathrm{SO}_{4}(\mathrm{mg} / \mathrm{L})$ & $3254 \mathrm{ppm}$ \\
\hline
\end{tabular}

glabra, Annona squamosa [25], Acacia arabica [26], Carica papaya [27], Azadirachta indica [28], and Vernonia amygdalina [29] for steel in acid media. The anticorrosion effect of Andrographis paniculata [30] and tea wastes [31] has been reported from our laboratories. Kliskic et al. analyzed aqueous extract of Rosmarinus officinalis [32] as corrosion inhibitor for aluminium alloy corrosion in chloride solution. Guar gum was analyzed for its anticorrosion activity by Abdallah [33]. Martinez and Stern have studied the inhibitory mechanism of low carbon steel corrosion of mimosa tannin in $\mathrm{H}_{2} \mathrm{SO}_{4}$ media [34]. Oguzie investigated the efficiency of Telfairia occidentalis extract as corrosion inhibitor in both $\mathrm{HCl}$ and $\mathrm{H}_{2} \mathrm{SO}_{4}$ media [35]. The extracts of chamomile, halfabar, black cumin, and kidney bean were analyzed for their inhibitive action of corrosion of steel in acid media by Abdel-Gaber et al. [36]. El-Hosary et al. [37] studied the corrosion inhibition of aluminium and zinc in $\mathrm{HCl}$ using Hibiscus sabdariffa extract. Rajendran et al. [38, 39] studied the corrosion inhibition of aluminium in rain water containing garlic extract. Aqueous extracts of rhizome powder [40], beet root extract [41], and Hibiscus rosa-sinensis have been used as corrosion inhibitors.

The present work is to examine the aqueous Jeera extract as an inhibitor for corrosion of carbon steel in solutioncontaining seawater. Weight loss measurements, potentiodynamic polarization, fluorescence, and UV-spectroscopy are used to study surface film formed on the metal surface.

\section{Experimental}

2.1. Preparation of Plant Extract of Jeera Extract. An aqueous plant extract was prepared by grinding $10 \mathrm{~g}$ of (Cuminum cyminum) extract, filtering, and making up to 100 using double distilled water.

2.2. Preparation of Specimens. Carbon steel specimens $(0.0267 \% \mathrm{~S}, 0.06 \% \mathrm{P}, 0.4 \% \mathrm{Mn}, 0.1 \% \mathrm{C}$, and the rest iron) of dimensions $1.0 \mathrm{~cm} \times 4.0 \mathrm{~cm} \times 0.2 \mathrm{~cm}$ were polished to a mirror finish and degreased with trichloroethylene.

2.3. Weight Loss Method. Relevant data of seawater used in the study are given in Table 1.

Carbon steel specimens in triplicate were immersed in $100 \mathrm{~mL}$ of the solutions containing various concentrations of the inhibitor for one day. The weight of the specimens before and after immersion was determined using Shimadzu balance, model AY 62. The corrosion products were cleansed with Clarke's solution [42]. The inhibition efficiency (IE) was then calculated using

$$
\text { I.E }=100\left[1-\left(\frac{W_{2}}{W_{1}}\right)\right] \%,
$$

where $W_{1}=$ corrosion rate in the absence of the inhibitor, and $W_{2}=$ corrosion rate in the presence of the inhibitor.

2.4. Surface Examination. The carbon steel specimens were immersed in various test solutions for a period of one day, taken out, and dried. The nature of the film formed on the surface of metal specimens was analyzed by FTIR spectroscopic study.

2.4.1. FTIR Spectra. FTIR spectra were recorded in a PerkinElmer 1600 spectrophotometer. The film was carefully removed and mixed thoroughly with $\mathrm{KBr}$ made in to pellets, and FTIR spectra were recorded.

The fluorescence spectra of the film formed on the CS samples recorded with a Hitachi F-4500 fluorescence spectrophotometer.

2.5. Potentiodynamic Polarization. A three-electrode cell consisting of mild steel as working electrode (WE), a platinum wire counter electrode (CE), and a saturated reference electrode was used for measurements. All the potential values reported here were VS SCE. The working electrode was mechanically polished on various grades of emery sheet, rinsed with double distilled water, and degreased with trichloroethylene. Potentiodynamic polarization curves were recorded using an $\mathrm{H}$ and $\mathrm{CH}$ electrochemical work station impedance analyzer model CHI $660 \mathrm{~A}$ provided with $i R$ compensation option. Polarization curve measurements were carried out at scan rate of $0.01 \mathrm{~V} \mathrm{~s}^{-1}$. The exposed area $\left(1 \mathrm{~cm}^{2}\right)$ was mechanically polished with a series of emery sheets of variable grades. The samples were washed thoroughly with double distilled water before insertion in the cell. During the polarization study, the scan rate was $0.01 \mathrm{~V} \mathrm{~s}^{-1}$, hold time at $E f$ was $0 \mathrm{~s}$, and quiet time was $2 \mathrm{~s}$.

2.6. Ac Impedance Measurements. The instrument used for polarization was used for AC impedance study also. The cell set-up was the same as that had been used for polarization measurements. The real part and imaginary part of the cell impedance were measured in ohms at various frequencies. The values of charge transfer resistance, $R_{\mathrm{ct}}$, and the double layer capacitance, $C_{\mathrm{dl}}$, were calculated. The equivalent electrical circuit diagram is shown in Figure 7.

\section{Result and Discussion}

3.1. Analysis of Results from Weight Loss Method. Table 2 shows the values of corrosion rates and inhibition efficiencies obtained from weight loss measurements of different concentrations of Jeera extract. $4 \mathrm{~mL}$ of the Jeera extract offered $93 \%$ corrosion inhibition efficiency to carbon steel immersed in $100 \mathrm{ml}$ solution containing seawater. When the 
TABLE 2: Corrosion rates (milligram per square decimeter per day) (Mdd) of carbon steel immersed in seawater in the presence and absence of inhibitors and the inhibition efficiencies (Ie) obtained by mass loss method. Inhibitor: Jeera extracts (Cuminum cyminum). Period of immersion: 1 day.

\begin{tabular}{lcc}
\hline Jeera extract & CR/mdd & Inhibition efficiency IE\% \\
\hline 0 & 21.52 & - \\
2 & 18.49 & 45 \\
4 & 2.35 & 93 \\
6 & 4.37 & 87 \\
8 & 14.46 & 51 \\
\hline
\end{tabular}

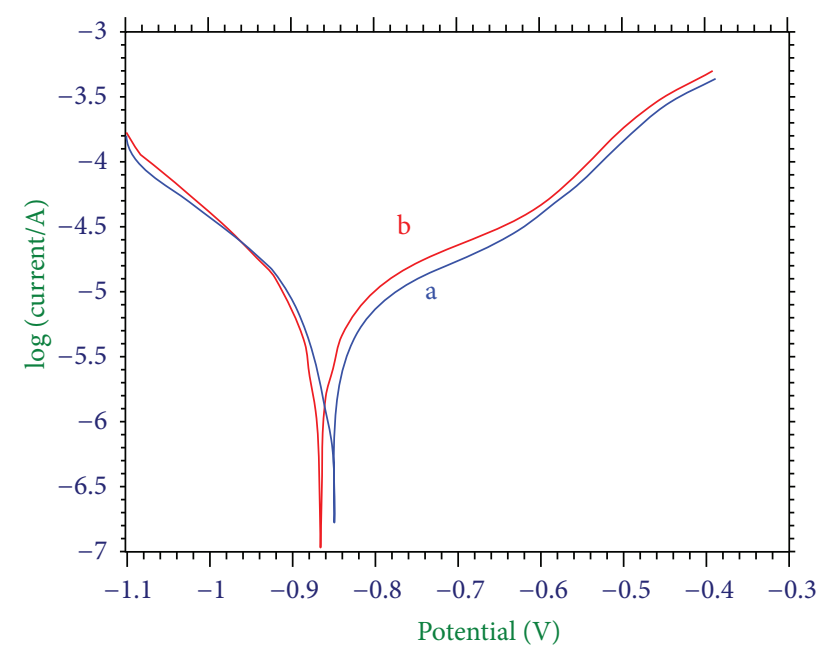

FIGURE 1: Polarization curves of carbon steel immersed in various test solutions: (a) seawater, (b) seawater + Jeera extract $4 \mathrm{~mL}$.

concentration of Jeera extract was increased, the inhibition efficiency decreased, and the corrosion rate increased, and this is due to the fact that when higher concentrations of Jeera extract are added, the protective film $\left(\mathrm{Fe}^{2+}\right.$-Cuminum cyminum complex) formed on the metal surface goes in to the solution and thus destroying the protective film. It may be considered that the protective film formed may go into transpassive state, where the film is broken [43].

3.2. Analysis of Polarization Curves. A polarization study has been used to detect the formation of protective film on the metal surface [44]. When a protective film formed on the metal surface, the linear polarization resistance (LPR) increases, and the corrosion current $\left(I_{\text {corr }}\right)$ decreases. The potentiodynamic polarization curves of carbon steel immersed in various test solution are shown in Figure 1. The corrosion parameters, namely, corrosion potential $\left(E_{\text {corr }}\right)$ tafel slopes $\left(b_{c}=\right.$ cathodic; $b_{\mathrm{a}}=$ anodic $)$, linear polarization resistance (LPR), and the corrosion current $\left(I_{\text {corr }}\right)$ are given in Table 3 when carbon steel is immersed in seawater. The corrosion potential of seawater is $-926 \mathrm{mV}$ VS SCE. The formulation consisting of $4 \mathrm{~mL}$ of Jeera extract in presence of seawater solution shifts the corrosion potential $-883 \mathrm{mV}$ VS SCE. This suggested that anodic reaction is controlled predominantly. The (LPR) value increases from $51.67 \times 10^{-2}$ to $63.67 \times$ $10^{-2} \mathrm{ohm} \mathrm{\textrm {cm } ^ { 2 }}$. This suggests that a protective film is formed

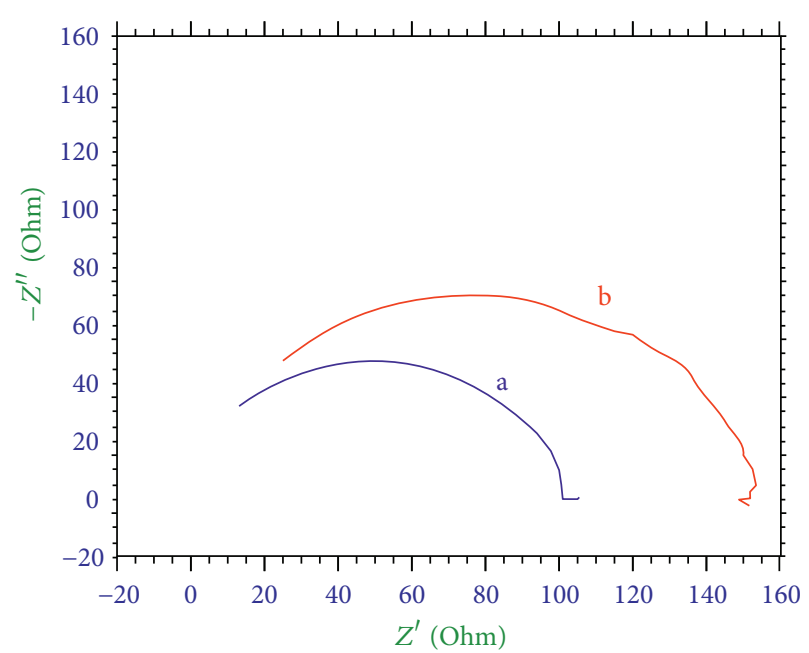

Figure 2: AC impedance spectra (Nyquist plots) of carbon steel immersed in various test solutions: (a) seawater, (b) seawater + Phyllanthus amarus $4 \mathrm{~mL}$.

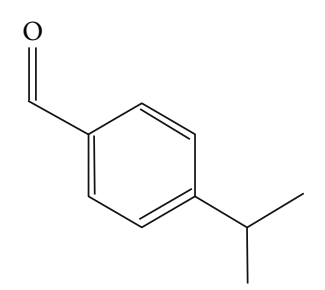

Scheme 1: Cuminaldehyde.

on the metal surface. Further the corrosion current decreases from $7.963 \times 10^{-6}$ to $6.295 \times 10^{-6} \mathrm{Acm}^{2}[45,46]$.

3.3. Analysis of Ac Impedance Spectra. AC impedance spectra have been used to detect the formation of the film formed on the metal surface. If the protective film is formed, the charges transfer resistance increases, and double layer capacitance value decreases [40]. The AC impedance spectra of carbon steel immersed in various solutions are shown in Figure 2 (Nyquist) and Figure 3 (impedance-Bode plots). The AC impedance parameter, namely, charge transfer resistance $\left(R_{\mathrm{ct}}\right)$ and double layer capacitance $\left(C_{\mathrm{dl}}\right)$ are given in Table 4 .

When carbon steel is immersed in aqueous solution containing seawater, the $R_{\mathrm{ct}}$ value is $88 \mathrm{ohm} \mathrm{cm}{ }^{2}$, and $C_{\mathrm{dl}}$ value is $1.027 \times 10^{-7} \mathrm{~F} / \mathrm{cm}^{2}$. When $4 \mathrm{ml}$ of (Cuminum cyminum) extract is added, the $R_{\mathrm{ct}}$ value increases from $88 \mathrm{ohm} \mathrm{cm}^{2}$ to $116 \mathrm{ohm} \mathrm{cm}^{2}$, and $C_{\mathrm{dl}}$ value decreases from $1.027 \times 10^{-7} \mathrm{~F} / \mathrm{cm}^{2}$ to $0.7817 \times 10^{-8}$. This suggest that a protective film is formed on the metal surface of the metal. Further there is increase in impedance $\log (\mathrm{Z} / \mathrm{ohm})$, value from 2.02 to 2.12 (derived from Bode plot shown in Figure 3).

3.4. Fourier Transfer-Infrared Spectra. The main constituent of Jeera extract is cuminaldehyde [47]. The structure of cuminaldehyde is shown in Scheme 1. It contain carboxylic group, cumin structure.

The Cuminum cyminum extract was evaporated to dryness to a solid mass. Its FTIR spectrum is shown in Figure 4(a). $-\mathrm{C}=\mathrm{C}$ stretching frequency appeared at $2141 \mathrm{~cm}^{-1}$. 
TABLE 3: Corrosion parameters of carbon steel immersed in seawater in the absence and presence of inhibitors.

\begin{tabular}{lccccc}
\hline System & $E_{\text {corr }} \mathrm{mV}$ versus SCE & $b_{\mathrm{c}} \mathrm{mV} /$ decade & $b_{\mathrm{a}} \mathrm{mV} / \mathrm{decade}$ & ${\mathrm{LPR} \mathrm{Ohm} \mathrm{cm}^{2}}^{I_{\text {corr }} \mathrm{A} / \mathrm{cm}^{2}}$ \\
\hline Seawater & -926 & 152 & 236 & $65.32 \times 10^{-2}$ & $6.164 \times 10^{-6}$ \\
Seawater + (Cuminum cyminum) extract $(4 \mathrm{~mL})$ & -883 & 153 & 247 & $51.67 \times 10^{-2}$ & $0.7963 \times 10^{-7}$ \\
\hline
\end{tabular}

TABLE 4: AC impedance parameters of carbon steel immersed in various solutions. Inhibitors: Jeera extract.

\begin{tabular}{lccr}
\hline System & $R_{\mathrm{ct}} \mathrm{ohm} \mathrm{\textrm {cm } ^ { 2 }}$ & $C_{\mathrm{dl}} \mathrm{F} / \mathrm{cm}^{2}$ & Impedance value log $(\mathrm{z} / \mathrm{ohm})$ \\
\hline Seawater & 88 & $1.027 \times 10^{-7}$ & 2.02 \\
$\mathrm{CC}(4 \mathrm{~mL})+$ Seawater & 128 & $7.0703 \times 10^{-8}$ & 2.17 \\
\hline
\end{tabular}
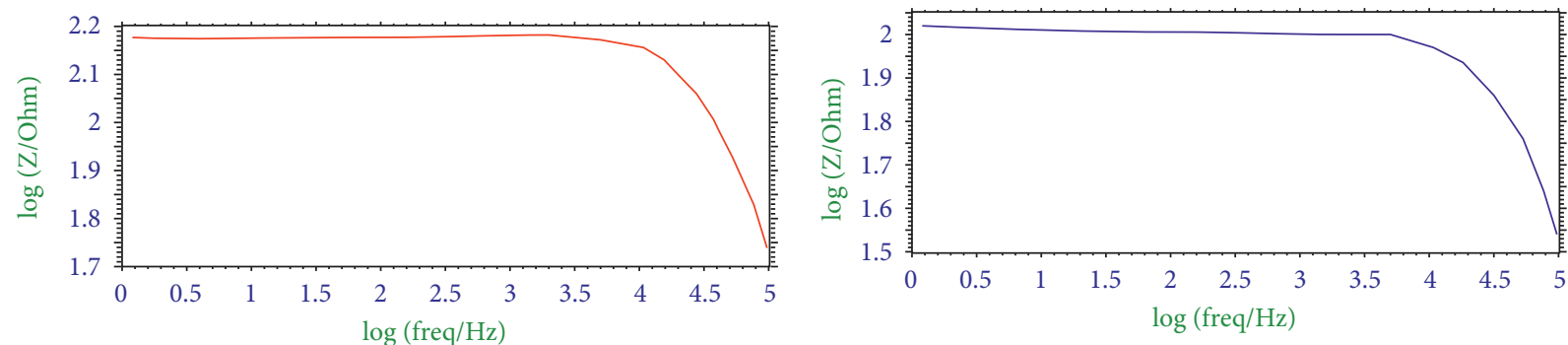

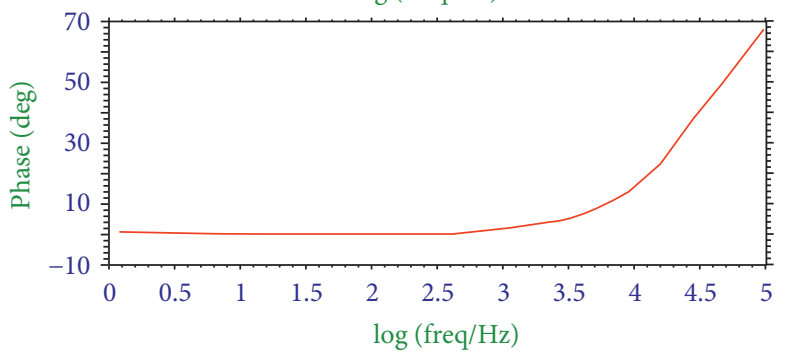

(a)

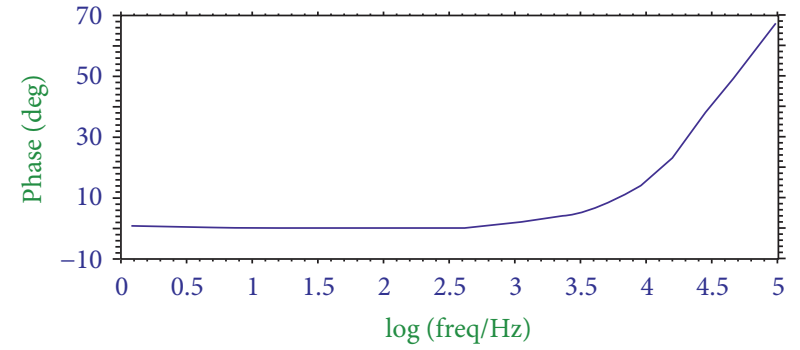

(b)

Figure 3: Bode plot of carbon steel immersed in various solutions (Bode plots). (a) Seawater, (b) Seawater $+4 \mathrm{ml}$ Jeera extract.

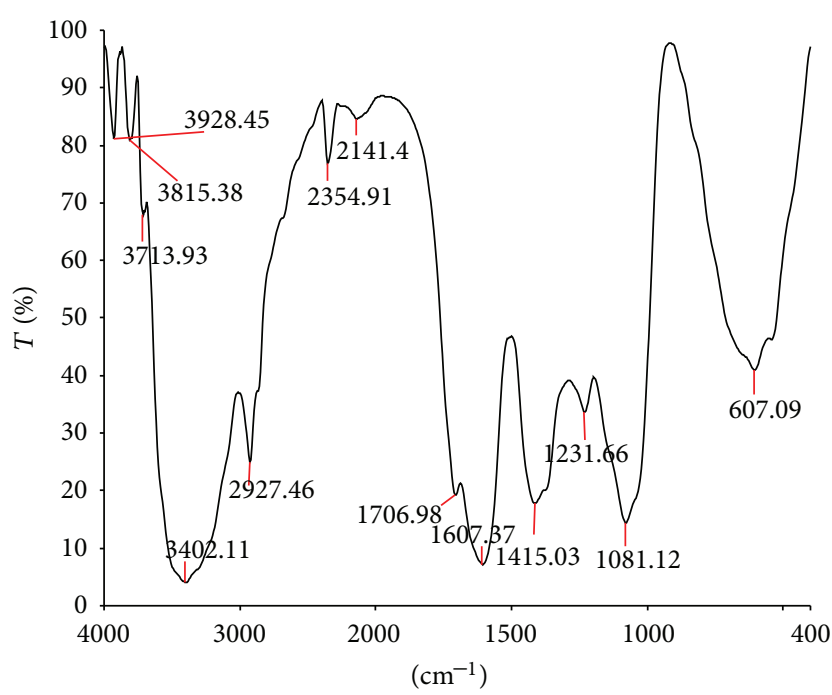

(a)

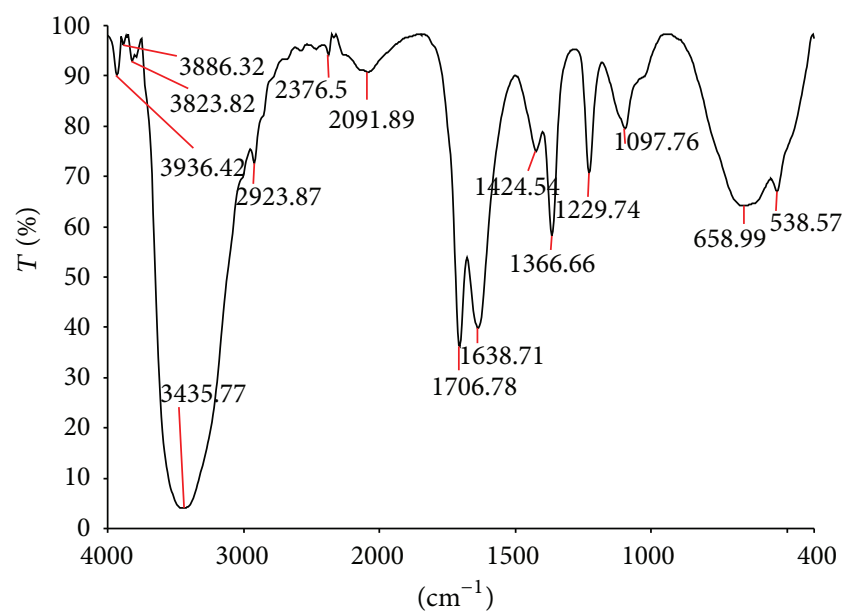

(b)

FIgURE 4: FTIR spectra. (a) Aqueous solution of Jeera extract, (b) Aqueous solution of seawater + Jeera extract $4 \mathrm{~mL}$. 


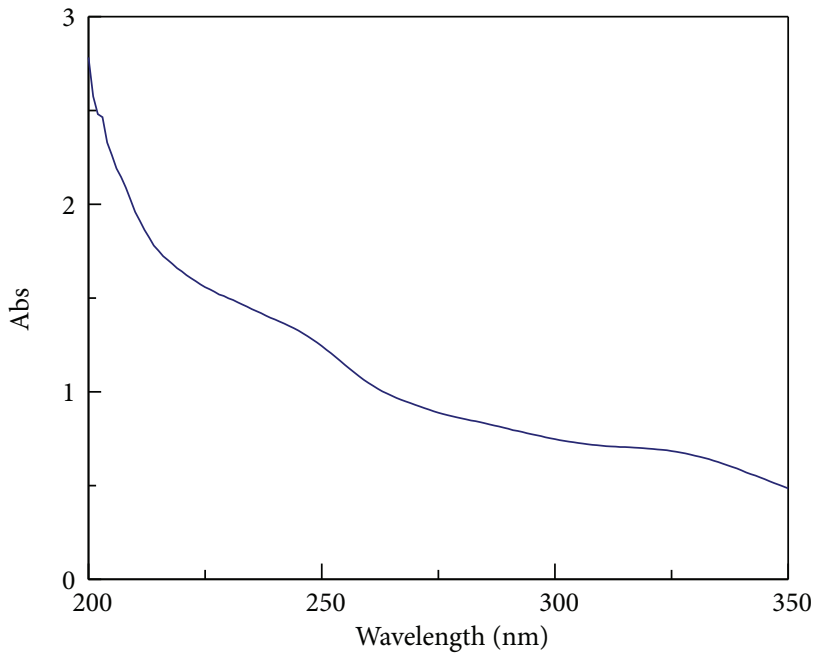

(a)

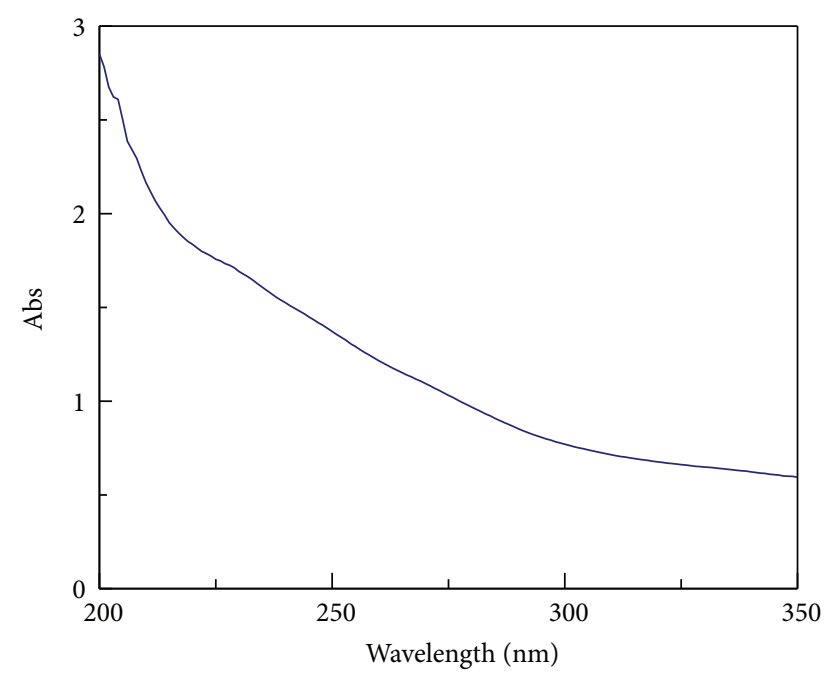

(b)

Figure 5: UV-spectra. (a) Aqueous solution of Jeera extract, (b) Aqueous solution of Jeera extract $+\mathrm{Fe}^{2+}$.

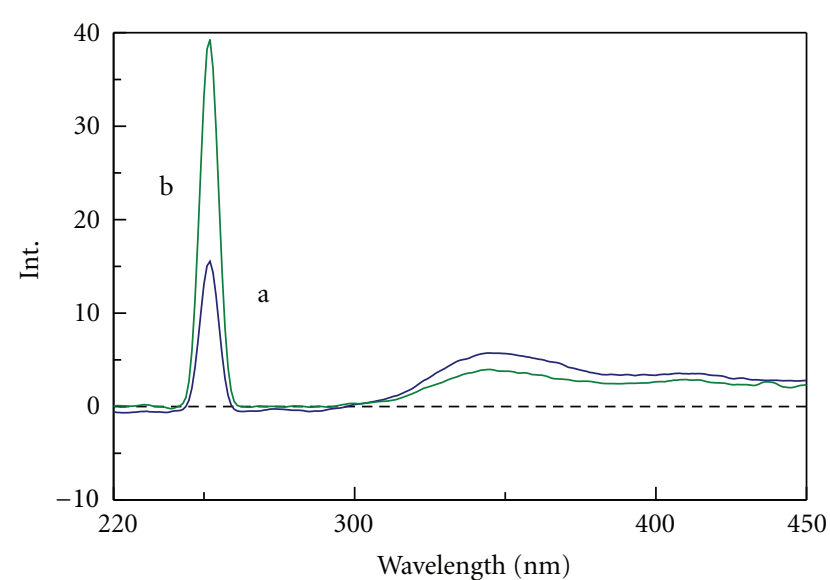

FIGURE 6: Fluorescence spectra. (a) Aqueous solution of Jeera extract, (b) film formed on the metal surface after immersion Jeera extract $+4 \mathrm{ml}$ Cuminum cyminum.

The aromatic $-\mathrm{CH}$ stretching frequency appeared at $2927 \mathrm{~cm}^{-1}$. $-\mathrm{C}=\mathrm{O}$ stretching frequency appeared at $1607 \mathrm{~cm}^{-1}[48,49]$.

The FTIR spectrum of the protective film formed on the surface of the metal after immersion in the aqueous solution containing seawater and Seawater containing $4 \mathrm{~mL}$ of Jeera extract is shown in Figure 4(b). - $\mathrm{OH}$ stretching frequency appeared at $3402 \mathrm{~cm}^{-1}$ to $3435 \mathrm{~cm}^{-1}$. $-\mathrm{C}=\mathrm{C}$ stretching frequency appeared at $2141 \mathrm{~cm}^{-1}$ to $2091 \mathrm{~cm}^{-1}$. The aromatic $-\mathrm{CH}$ stretching frequency appeared at $2927 \mathrm{~cm}^{-1}$ to $2923 \mathrm{~cm}^{-1}$. $-\mathrm{C}=\mathrm{O}$ stretching frequency appeared at $1607 \mathrm{~cm}^{-1}$ to $1638 \mathrm{~cm}^{-1}$.

3.5. Fluorescence Spectra. The UV-visible adsorption spectrum of aqueous solution of Cuminum cyminum and $\mathrm{Fe}^{2+}$ is shown in Figure 5. Peaks appear at $228 \mathrm{~nm}, 268 \mathrm{~nm}$. When the

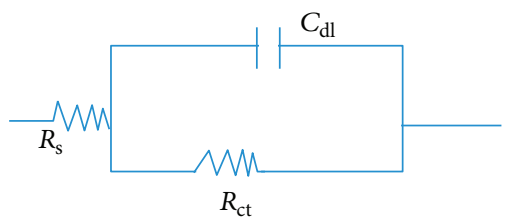

Figure 7: Equivalent electrical circuit diagram. $R_{\mathrm{s}}$ : solution resistance; $R_{\mathrm{ct}}$ : charge transfer resistance; $C_{\mathrm{dl}}$ : double layer capacitance.

$\mathrm{Fe}^{2+}$ sis added to the aqueous solution of Cuminum cyminum, peak appears at $225 \mathrm{~nm}$ and $265 \mathrm{~mm}$ [46].

The fluorescence spectrum $\left(\lambda_{\mathrm{ex}}=225 \mathrm{~nm}\right)$ of an aqueous solution of $\mathrm{Fe}^{2+}$-Cuminum cyminum is shown in Figure 6(a). A peak appears at $252 \mathrm{~nm}$. This due to that $\mathrm{Fe}^{2+}$-active principle complex is formed in solution [40].

The fluorescence spectrum $\left(\lambda_{\mathrm{ex}}=225 \mathrm{~nm}\right)$ of the film formed on the surface of the metal after immersion in the solution containing seawater and $4 \mathrm{ml}$ of Cuminum cyminum extract is shown in Figure 6(b). The peaks appeared at $252 \mathrm{~nm}$ confirming the presence of $\mathrm{Fe}^{2+}$-Cuminum cyminum extract complex formed on the metal surface.

\section{Conclusion}

The corrosion inhibition by aqueous solution of Jeera extract in the presence and absence of inhibitor was studied by weight-loss study and electrochemical measurements. The results show that inhibitor has the ability of reducing the corrosion rate of carbon steel in aqueous solution containing Jeera extract, and it acts as an anodic inhibitor. This effectiveness is confirmed by electrochemical impedance spectra and potential polarization analysis.

\section{Acknowledgment}

The authors are thankful to DRDO, India, for help and encouragement and to Mrs R. Nagalakshmi for useful suggestions. 


\section{References}

[1] A. A. El Hosary, R. M. Saleh, and A. M. Shams El Din, "Corrosion inhibition by naturally occurringsubstances-I. The effect of Hibiscus subdariffa (karkade) extract on the dissolution of $\mathrm{Al}$ and Zn," Corrosion Science, vol. 12, no. 12, pp. 897-904, 1972.

[2] A. A. El Hosary and R. M. Saleh, Progress in Understanding and Prevention of Corrosion, vol. 2, The Institute of Materials, London, UK, 1993.

[3] C. A. Loto, "The effect of Vernonia amygdalina (bitter leaf) solution extract on the corrosion inhibition of mild steel," Nigerian Corrosion Journal, vol. 19, pp. 20-28, 1998.

[4] G. O. Avwiri and F. O. Igho, "Inhibitive action of Vernonia amygdalina on the corrosion of aluminium alloys in acidic media," Materials Letters, vol. 57, no. 22-23, pp. 3705-3711, 2003.

[5] G. Gunasekaran and L. R. Chauhan, "Eco friendly inhibitor for corrosion inhibition of mild steel in phosphoric acid medium," Electrochimica Acta, vol. 49, no. 25, pp. 4387-4395, 2004.

[6] K. O. Orubite and N. C. Oforka, "Inhibition of the corrosion of mild steel in hydrochloric acid solutions by the extracts of leaves of Nypa fruticans Wurmb," Materials Letters, vol. 58, no. 11, pp. 1768-1772, 2004.

[7] A. Y. El-Etre, "Natural honey as corrosion inhibitor for metals and alloys. I. Copper in neutral aqueous solution," Corrosion Science, vol. 40, no. 11, pp. 1845-1850, 1998.

[8] A. Y. El-Etre and M. Abdallah, "Natural honey as corrosion inhibitor for metals and alloys. II. C-steel in high saline water," Corrosion Science, vol. 42, no. 4, pp. 738-738, 2000.

[9] A. Y. El-Etre, "Inhibition of acid corrosion of aluminum using vanillin," Corrosion Science, vol. 43, no. 6, pp. 1031-1039, 2001.

[10] A. Y. El-Etre, "Inhibition of aluminum corrosion using Opuntia extract," Corrosion Science, vol. 45, no. 11, pp. 2485-2495, 2003.

[11] A. Y. El-Etre, M. Abdallah, and Z. E. El-Tantawy, "Corrosion inhibition of some metals using lawsonia extract," Corrosion Science, vol. 47, no. 2, pp. 385-395, 2005.

[12] A. Chetouani and B. Hammouti, "Corrosion inhibition of iron in hydrochloric acid solutions by naturally henna," Bulletin of Electrochemistry, vol. 19, no. 1, pp. 23-25, 2003.

[13] Chetouani, "Etude Numerique de problemes non linear at application aux problemes de dynamique de population," [Ph.D. thesis], University Oujda, Oujda, Morocco, 2003.

[14] B. Hammouti, S. Kertit, and M. Mellhaoui, "Bgugaine: a natural pyrollidine alkaloid product as corrosion inhibitor of iron in $\mathrm{HCl}$ medium," Bulletin of Electrochemistry, vol. 11, p. 553, 1995.

[15] B. Hammouti, S. Kertit, and A. Melhaoui, "Electrochemical behaviour of bgugaine as a corrosion inhibitor of iron in $1 \mathrm{M}$ HCl," Bulletin of Electrochemistry, vol. 13, no. 3, pp. 97-98, 1997.

[16] S. Kertit, B. Hammouti, and M. Mellhaoui, "Bgugaine comme inhibitor de corrosion du fer en milieu acide chlorhydrique," Moroccan Patent no. 23910, 1995.

[17] R. M. Saleh and A. A. El-Hosaray, "Corrosion inhibition by naturally occuring substance-I the effect of Hibiscus subdariffa (Karkade) extract on the dissolution of $\mathrm{Al}$ and $\mathrm{Zn}$," in Proceedings of the 13th Seminar on Electrochemistry, CECRI, Karaikudi, India, 1972.

[18] A. El-Hosary, M. M. Gowish, and R. M. Saleh, "Evaluation of quinolines as inhibitors by electrochemical techniques," in Proceedings of the 2nd International Symposium and Oriented Basic Electrochemistry, vol. 7, SAEST, IIT, Madras, Technical Session, 1980, paper 6.24.
[19] J. Arockia Selvi, S. Rajendran, V. Ganga Sri, A. John Amalraj, and B. Narayanasamy, "Corrosion inhibition by beet root extract," Portugaliae Electrochimica Acta, vol. 27, no. 1, pp. 1-11, 2009.

[20] M. J. Sanghvi, S. K. Shukla, A. N. Mishra, M. R. Padh, and G. N. Mehta, 5th National Congress on Corrosion Control, New Delhi, India, 1995.

[21] M. J. Sanghvi, S. K. Shukla, A. N. Mishra, M. R. Padh, and G. N. Mehta, "Formulation of $5 \% \mathrm{HCl}$ corrosion inhibition for mild steel using weight loss and DC polarization technique," in International Conference on Maintenance, Inspection, Corrosion, Materials Engineering and Plant Reliability Baroda (MICMEP '99), vol. 84-87, p. 87, Baroda, India, February 1999.

[22] S. J. Zakvi and G. N. Mehta, "Acid corrosion of mild steel and its inhibition by swertia aungustifolia-study by electrochemical techniques," Transactions of the SAEST, vol. 23, no. 4, pp. 407-410, 1988.

[23] P. Kar, A. Hussein, G. Varkey, and G. Singh, "Corrosion inhibition of mild steel in hydrochloric acid by acid entacts of sapindus trifolianus, acaciaconcian and Trifla, Trans," MFAI, vol. 51, pp. 143-147, 1996.

[24] S. A. Verma and G. N. Mehta, "Effects of acid extracts of powered seeds of Eugenia Jambolans on corrosion of mild steel in HCl-study by DC polarisation techniques," Transactions of the SAEST, vol. 32, no. 4, pp. 89-93, 1997.

[25] P. Sakthivel, P. V. Nirmala, S. Umamaheswari et al., "Corrosion inhibition of mild steel by extracts of Pongamia Glabra and Annona Squamosa in acidic media," Bulletin of Electrochemistry, vol. 15, no. 2, pp. 83-86, 1999.

[26] S. Verma and G. N. Mehta, "Effect of acid extracts of acacia arabica on acid corrosion of mild steel," Bulletin of Electrochemistry, vol. 15, no. 2, pp. 67-70, 1999.

[27] U. J. Ekpe, E. E. Ebenso, and U. J. Ibok, "Inhibitory action of Azadirachta indica leaves extract on the corrosion of mild steel in $\mathrm{H}_{2} \mathrm{SO}_{4}$," West African Journal of Biological and Applied Chemistry, vol. 37, pp. 13-30, 1994.

[28] U. J. Ekpe, E. E. Ebenso, and U. J. I. Ibok, Journal of the West African Science Association, vol. 37, p. 13, 1994.

[29] A. Loto, "The effect of bitterleaf extracts on corrosion of mild steel in $0.5 \mathrm{M} \mathrm{HCl}$ and $\mathrm{H}_{2} \mathrm{SO}_{4}$ solutions," Nigerian Corrosion Journal, pp. 19-20, 1998.

[30] S. P. Ramesh, K. P. Vinod Kumar, and M. G. Sethuraman, "Extract of andrographis paniculata as corrosion inhibitor of mild steel in acid medium," Bulletin of Electrochemistry, vol. 17, no. 3, pp. 141-144, 2001.

[31] M. G. Sethuraman, P. Vadivel, and K. P. Vinod Kumar, "Tea wastes as corrosion inhibitor for mild steel in acid medium," Journal of the Electrochemical Society of India, vol. 50, p. 143, 2001.

[32] M. Kliskic, J. Radosevic, S. Gudic, and V. Katalinic, "Aqueous extract of Rosmarinus officinalis L. as inhibitor of Al-Mg alloy corrosion in chloride solution," Journal of Applied Electrochemistry, vol. 30, no. 7, pp. 823-830, 2000.

[33] M. Abdallah, "Guar gum as corrosion inhibitor for carbon steel in sulfuric acid solutions," Portugaliae Electrochimica Acta, vol. 22, pp. 161-175, 2004.

[34] S. Martinez and I. Stern, "Inhibitory mechanism of low-carbon steel corrosion by mimosa tannin in sulphuric acid solutions ," Journal of Applied Electrochemistry, vol. 31, no. 9, pp. 973-978, 2001. 
[35] E. Oguzie, "Inhibition of acid corrosion of mild steel by Telfaria occidentalis," Pigment and Resin Technology, vol. 34, no. 6, pp. 321-326, 2005.

[36] M. Abdel-Gaber, B. A. Abd-El-Nabey, I. M. Sidahmed, A. M. El-Zayaday, and M. Saa dawy, "Inhibitive action of some plant extracts on the corrosion of steel in acidic media," Corrosion Science, vol. 48, no. 9, pp. 2765-2779, 2006.

[37] A. El-Hosary, R. M. Saleh, and A. M. Sharns El Din, "Corrosion inhibition by naturally occurringsubstances-I. The effect of Hibiscus subdariffa (karkade) extract on the dissolution of $\mathrm{Al}$ and Zn," Corrosion Science, vol. 12, no. 12, pp. 897-904, 1972.

[38] S. Rajendran, S. Muthulakshmi, R. Rajeswari, and A. Vijitha, "Emerging trends in corrosion science and engineering," Journal of the Electrochemical Society of India, vol. 54, no. 2, p. 61.

[39] S. Rajendran and K. Anuradha, "Corrosion behaviour of aluminium in rain water containing garlic extract," Surface Engineering, vol. 21, no. 3, pp. 229-231, 2005.

[40] S. Rajendran, S. Shanmugapriya, T. Rajalakshmi, and A. J. Amal Raj, "Corrosion inhibition by an aqueous extract of rhizome powder," Corrosion, vol. 61, no. 7, pp. 685-692, 2005.

[41] S. Rajendran, J. Arokiaselvi, and V. Gangasree, "Corrosion inhibition by beet root extract," Protugalia Electrochemica Acta, vol. 27, no. 1, pp. 1-11, 2009.

[42] G. Wranglen, Introduction to Corrosion and Protection of Metals, vol. 236, Chapman \& Hall, London, UK, 1985.

[43] J. Sathyabama, R. Susai, S. J. Arokia, and A. A. John, "Methyl orange as corrosion inhibitor for carbon steel in well water," Indian Journal of Chemical Technology, vol. 15, pp. 462-466, 2008.

[44] S. Rajendran, S. P. Sridevi, N. Anthony, A. J. Amalraj, and M. Sundaravadivelu, "Corrosion behaviour of carbon steel in polyvinyl alcohol," Anti-Corrosion Methods and Materials, vol. 52, no. 2, pp. 102-107, 2005.

[45] F. R. Selvarani, S. Santhamadharasi, J. W. Sahayaraj, A. J. Amalraj, and S. Rajendran, "Synergistic effect of succinic acid and $\mathrm{Zn}^{2+}$ in controlling corrosion of carbon steel," Bulletin of Electrochemistry, vol. 20, no. 12, pp. 561-565, 2004.

[46] S. Rajendran, S. M. Reenkala, N. Anthony, and R. Ramaraj, "Synergistic corrosion inhibition by the sodium dodecylsulphate- $\mathrm{Zn}^{2+}$ system," Corrosion Science, vol. 44, no. 10, pp. 2243-2252, 2002.

[47] N. S. Iacobellis, P. Lo Cantore, F. Capasso, and F. Senatore, "Antibacterial activity of Cuminum cyminum L. and Carum carvi L. essential oils," Journal of Agricultural and Food Chemistry, vol. 53, no. 1, pp. 57-61, 2005.

[48] S. Agnesia Kanimozhi and S. Rajendran, "Inhibitive properties of sodium tungstate- $\mathrm{Zn}^{2+}$ system and its synergism with HEDP," International Journal of Electrochemical Science, vol. 4, pp. 353-368, 2009.

[49] R. M. Silver stein, G. C. Bassler, and T. C. Morrill, Spectroscopic Identification of Organic Compound, vol. 95, John Wiley \& Sons, New York, NY, USA, 1986. 

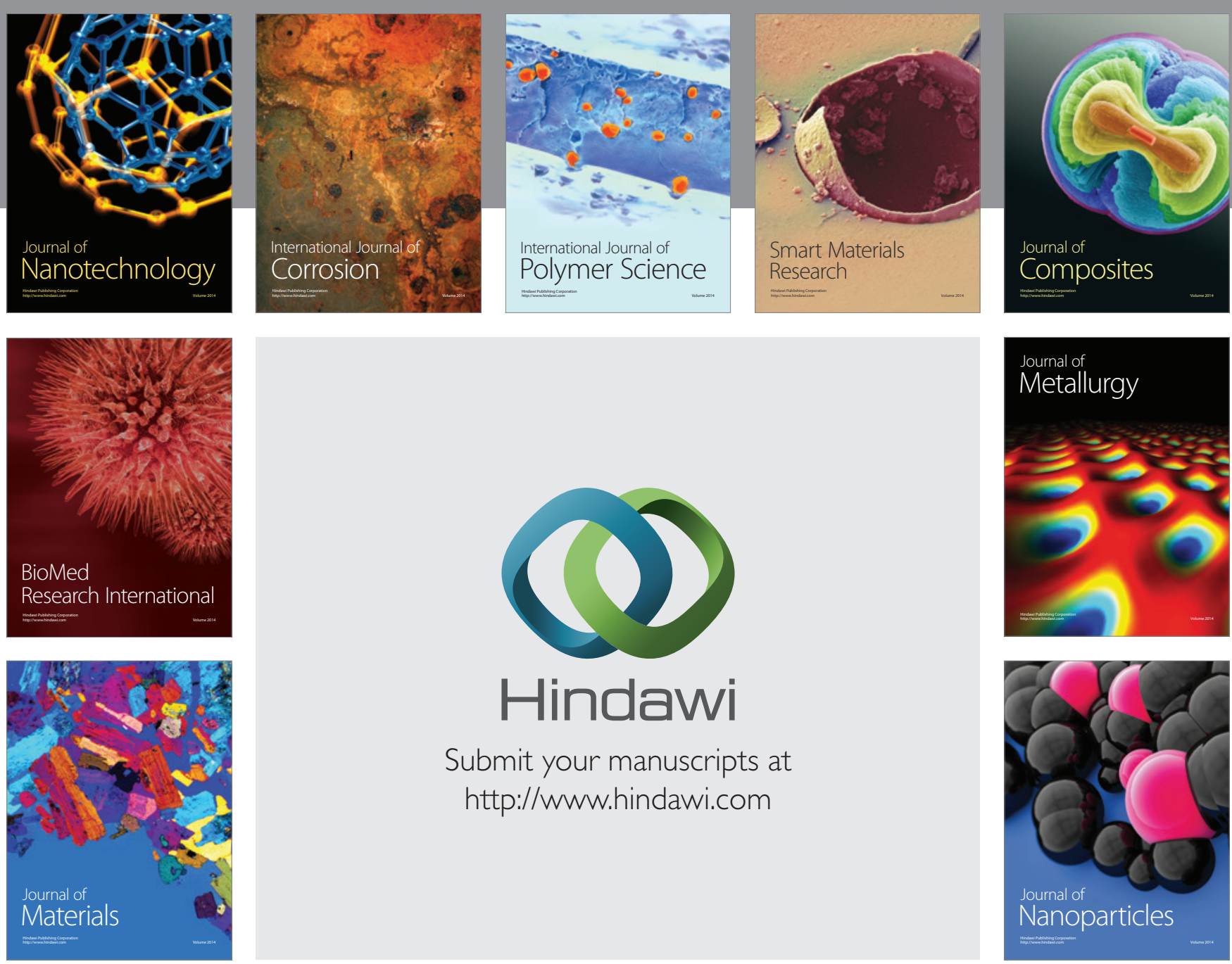

Submit your manuscripts at http://www.hindawi.com
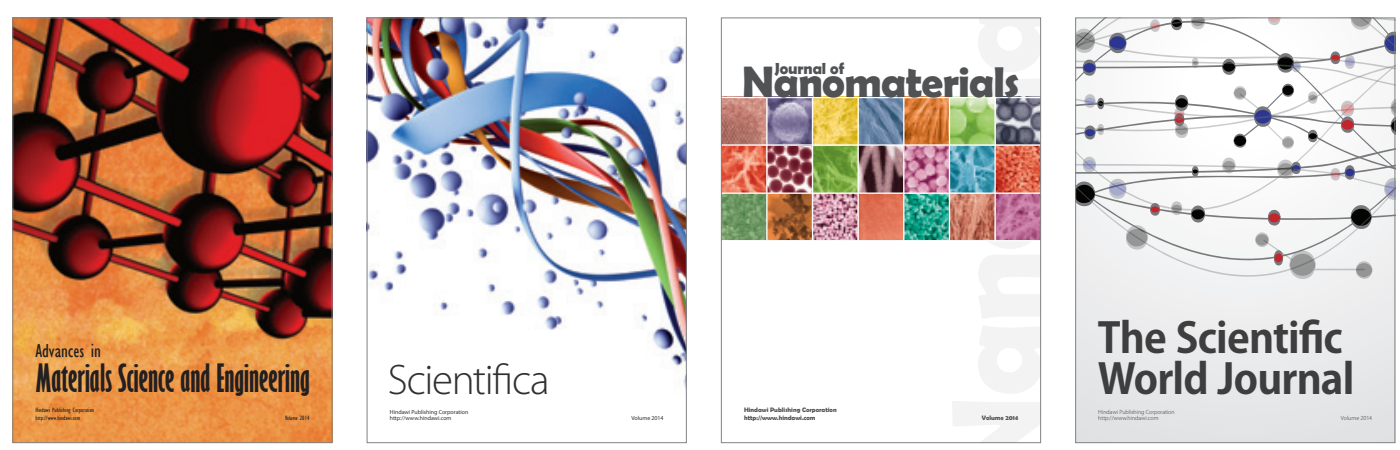

\section{The Scientific World Journal}
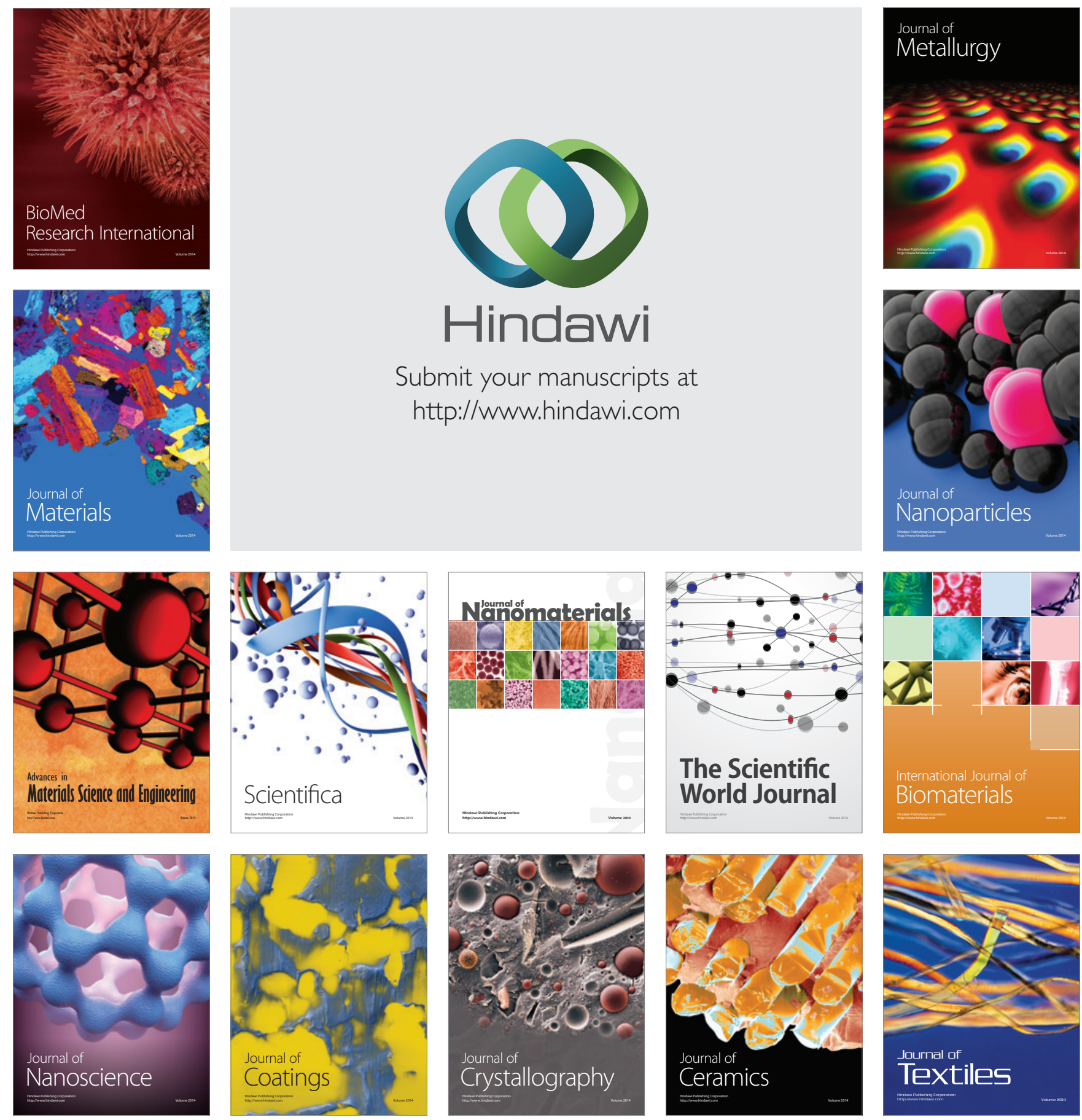